\title{
PSYCHE
}

\begin{tabular}{lll}
\hline VOL. XLIV DECEMBER, 1937 & No. 4 \\
\hline
\end{tabular}

\section{NOTES ON THE HABITS OF STRUMIGENYS}

\section{By William Steel Creighton}

Dept. of Biology, College of the City of New York

The singular cephalic characteristics which mark the ants of the genus Strumigenys have given rise to a number of postulates concerning the habits of these strange insects. Such postulates have, for the most part, remained speculative. This result is not surprising if one considers the obscurity which surrounds these forms. Although widely distributed and not excessively rare in some areas Strumigenys is one of the least conspicuous genera in our ant fauna. This will not, however, entirely account for the dearth of ecological data concerning the group. Published records attest that nearly every American myrmecologist has taken specimens of Strumigenys in the field. The opportunity for habit studies has been allowed to pass and the specimens have given rise to little more than an additional locality record. If it were not for the abundant evidence to the contrary one might almost believe that myrmecologists suffer from a distressing sort of alcoholism which impells them to pop rare specimens into that fluid as soon as these are unearthed. This might have been the fate of the colony described in this paper had it not been accidentally divided into two groups on exposure. The first of these went into alcohol at once but the second was not noticed until the initial acquisitive frenzy had passed. It was thereupon placed in a live-bottle where it survived a three day trip home. The ensuing notes are based upon observations made on this fragment of the original colony. 
I regard the specimens as identical with that form of $S$. louisianae described by Dr. M. R. Smith as the subspecies laticephala. It may be recalled that Dr. Smith in his monograph of the North American Strumigenys (1) expressed the belief that the range of the subspecies laticephala might be more extensive than his published records indicated. The locality of the colony described herein fully supports Dr. Smith's supposition and at the same time furnishes a new northeastern record not only for the subspecies but for the subgenus as well. The insects were secured on April 22 in a well-developed stand of pine a mile or two to the east of Rocky Mount, North Carolina. The previous records of this subspecies were limited to Mississippi and Alabama where its known range extended almost to the northern border of each state. In point of fact the North Carolina record is only about eighty miles further to the north but the wide swing to the east is very significant. It definitely places laticephala with that interesting group of southern species whose range begins in the Gulf States and extends northward through the tidewater area of the Atlantic seaboard. It is, perhaps, not too much to assume that the northern end of the range of laticephala may lie in the New Jersey pine barrens.

On reaching home the fifteen surviving workers were placed in a small plaster nest. In addition I placed in the nest chambers a quantity of the bark which had formed the walls of the original nest. Except for shredding this bark so that it would not interfere with the closing of the glass top of the nest it was in its original condition. This was done with a view to promoting fungal growth since Kennedy and Schramm, in a paper published in 1933 (2) had postulated that these insects might be fungus feeders. Their supposition was based upon an analysis of $S$. (Cephaloxys) ohioensis, a species which they described in the same paper. After boiling the insects in $\mathrm{KOH}$ the cleared specimens were examined for chitinous remains of other insects. The results were negative, no such fragments being found. Accordingly Kennedy and Schramm gave up the idea that Strumigenys is insectivorous because they believe that such fragments occur "in the bodies of other ants which feed on insects". I find this statement confusing. I presume that it must refer to the infra-buccal pocket which sometimes contains chitinous 
remains. I cannot believe that the authors imply that such fragments pass into the abdominal portion of the digestive tract. If the infrabuccal pocket is meant, however, it should be recalled that Wheeler and Bailey have clearly shown (3) that this structure may be entirely devoid of recognizable insect remains in the case of an ant known to be insectivorous. The absence of such remains is, therefore, no proof that insect tissues are not used as food. While I could not accept the above conclusion as offered I was anxious to test the hypothesis of the two authors that the ants might be fungus feeders. This seemed entirely amenable to investigation if living specimens were available for study. I determined, therefore, to give the colony every opportunity for cultivating a food fungus. With this in mind the nest was kept very moist and there soon developed on the surface of the bark two distinctly different fungi.

The first of these appeared during the initial twenty-four hours after the establishment of the artificial nest. It consisted of numerous, slender, twisted hyphae. These colorless strands strongly resembled the filaments of Rhizopus but they never formed a heavy mycelium nor, as far as I could tell, did they ever produce fruiting bodies. The second fungus appeared on the following day. It consisted of spherical tufts of short hyphae radially arranged around what seemed to be a central point of attachment. The diameter of the mature colony was about one millimeter and as they approached maturity the color changed from white to bluegrey. As each tuft seemed entirely isolated and as they showed a progressive development through the nest chambers it seems likèly that this second fungus may have formed spores although I never saw any.

During the course of many hours of observation I saw the Strumigenys repeatedly crawl around and over each of the two fungi. When doing so they would touch the hyphæ with their antennæ but, as they constantly explore their surroundings with these organs while moving, there is no reason to attribute special significance to this fact. In no case did I see any evidence of the ants feeding on the fungus and it was only rarely that the palps came in contact with them. It may be argued that neither of the two fungi which developed on the bark was the hypothetical food fungus. I see 
no reason to suppose that such a view can be maintained. From what we know of the Attine ants there is abundant evidence to show that the fungus feeders permit only the food fungus to develop in the nest. Moreover, while the full development of the mycelia of such a fungus is usually restricted to the actual garden, fragments of the hyphæ are widely dispersed throughout the nest because they adhere to the bodies of insects which tend them. From what has been said above it is obvious that the conditions in the artificial nest were favorable to the growth of fungi. If the ants had been cultivating a food fungus it is scarcely thinkable that it should have failed to develop while two foreign fungi grew well.

It may further be objected that Kennedy and Schramm applied their postulate to a member of the subgenus Cephaloxys while my observations were made upon a species belonging to the subgenus Strumigenys. I am ready to agree that the habits of the two groups may differ but I would incline to the view that of the two Cephaloxys might be expected to show more nearly general feeding habits than Strumigenys. The mandibles of most species of Cephaloxys are far less aberrant than those of Strumigenys and, in addition, the workers of Cephaloxys forage outside the nest in a perfectly normal manner. I have been able to observe this forraging in the case of three species of Cephaloxys and do not doubt that the other members of the group behave in a similar fashion. On the other hand I have never seen a worker of the subgenus Strumigenys outside the nest although I have taken these insects in several localities. There is, perhaps, little need for such elaborate refutation when it can be stated that the members of the captive colony readily fed on the tissues of other insects or, when these were not available, on a mixture of egg yolk and sugar. They refused sugary foods containing little protein. Indeed they were the first ants which I have ever known to reject a diet of bananas. With these observations in mind it seems to me that one cannot escape the conclusion that under natural conditions Strumigenys is insectivorous. ${ }^{1}$

${ }^{1}$ After this article had gone to press the author received from Mr. L. G. Wesson, Jr., a most interesting paper describing his studies on the feeding habits of Strumigenys pergandei. (Entomological News, 
We now come to another postulate concerning the habits of Strumigenys which was advanced by the author in a paper published in 1930 (4). This publication, primarily concerned with the genus Myrmoteras, carried introductory remarks on various genera possessing linear mandibles. The matter of retrosalience was necessarily discussed but I attempted to show that this phenomenon represented the fortuitous outcome of a type of mandibular organization which I styled "trap-jawed". I pointed out that such mandibular apparatus would be a very decided advantage to sluggish ants enabling them to capture other insects more agile than themselves. It is gratifying to be able to state that this supposition has proven correct in the case of Strumigenys. Because much of what is to follow presupposes a knowledge of the structure of the mandibles of Strumigenys I have prefaced the account of their activities with the needful morphological description.

Each mandible of S. louisianae subsp. laticephala (Fig. 1) is inserted close to the midline of the head and consists of a rather stout blade which is rounded on the outer face and flattened on the inner. This blade bears two prominent apical teeth and a third subapical tooth which is about half as long as the other two. All three teeth are sharp and slender and set at right angles to the long axis of the blade. As the tip of the blade is somewhat rounded at the rear of the two apical teeth the resulting structure is not unlike what would be produced if the tines of a fork were bent at right angles to the handle. There is, however, this difference, the "fork" has only two tines and these are separated by the thickness of the blade of the mandible. There is thus a considerable space between the apical teeth, a fact which will be later shown to be of importance. When in repose the mandibles can be brought close together so that their inner faces are almost in contact. This appears to be the usual

\footnotetext{
Vol. 47, No. 7, pp. 171-174, 1936.). Mr. Wesson showed that the normal food of this ant consists of various species of springtails. The Collembola are hunted down by the ants but not seized until they blunder into the open mandibles of their captors. Mr. Wesson considers that the presence of various species of Strumigenys in the nests of other ants constitutes what he calls a "loose form of symbiosis." The Strumigenys benefit because of the abundant supply of springtails and are tolerated by the other ant which may benefit by the removal of the springtails.
} 
position of the mandibles. I am by no means certain that the inner faces ever actually come in contact with each other although it seems likely that such contact may follow the snapping together of the mandibles during an attack. When the mandibles are held in the position just described the apical teeth lie close together and parallel to each other with their tips extending beyond the inner border of the opposite mandible (Fig. 2). If one looks down the long axis of the closed mandibles the four apical teeth may be seen to enclose a diamond-shaped area whose size will depend upon the degree of closure of the mandibles (Fig. 3). The mandibles can be opened to an astonishing extent, their outer borders approaching the sides of the head under extreme conditions. As a rule, however, they are not opened so widely, their usual position during attack being approximately at right angles to the long axis of the head. Under such circumstances the trigger hairs may be readily seen (Fig. 4). These do not arise from the mandibles themselves, as is the case with other forms possessing similar gnathal apparatus, but are borne on two conical lobes which lie between the bases of the mandibles. The trigger hairs are about two-thirds as long as the mandibles, and, since they project forward, it may be readily seen that objects which they touch should lie within the arcs described by the closing jaws. Anyone familiar with the mandibular organization of Odontomachus or Anochetus will recognize the essential similarity of the structures just described in Strumigenys. Since we know that Odontomachus is able to dismember other insects with its pincer-like mandibles it seems reasonable to expect analogous reactions in the case of Strumigenys. My observations have supported this expectation but it must be borne in mind that the exceedingly deliberate actions of Strumigenys result in a type of attack which appears very different from the energetic activities of Odontomachus.

As soon as the colony had recovered from the shock of transplantation and seemed at home in its new surroundings I cast about for a suitable victim with which to test the idea just mentioned. The small size of the Strumigenys worker considerably limited the choice. I wished to have the victim a more active insect than the Strumigenys and prudence forbade the use of any form which might possibly damage the 
Strumigenys during the attack. With these points in mind I selected Brachymyrmex heeri var. depilis as most suitable although under natural conditions it may be doubted if the two species often come in contact. For my purposes the choice was a most satisfactory one for each of the thirteen Brachymyrmex workers introduced into the nest was killed by the Strumigenys although some of them managed to avoid death for a number of hours. The method of attack employed by the Strumigenys was remarkably constant, so much so that I feel it unnecessary to cite individual cases unless there is some point of special interest.

The sequence of events was as follows:

On admitting the Brachymyrmex to the nest it began a series of exploratory investigations during which it visited the various nest chambers. As the Strumigenys preferred to stay in one of the narrow passages connecting two of the chambers it frequently happened that the Brachymyrmex actually ran over the quiescent Strumigenys workers. The latter roused at once and opened the mandibles but it seldom happened that any of them struck at the Brachymyrmex at that time. It may be added that, until it was attacked, the Brachymyrmex showed little fear of the Strumigenys. After becoming aware of the presence of the Brachymyrmex the Strumigenys workers would begin to move slowly about the nest. It is hard to depict the extreme deliberation of their movements. They proceed literally a step at a time and this gives to their actions an air of stealth which is probably spurious since they never move rapidly under any circumstances. Eventually one or more of the Strumigenys workers would approach within striking distance of the Brachymyrmex. If the latter were quiet the attacker would locate its position by cautious explorations with the antenna before it struck. Not infrequently, however, the Brachymyrmex blundered into the open jaws of the Strumigenys which were promptly snapped shut as the trigger hairs were touched. The closure of the mandibles is extremely rapid and is followed by a distinct backward jerk of the body of the attacker. These two movements seem to be the only rapid motions of which the Strumigenys worker is capable. The effect of the attack on the Brachymyrmex is very marked. It would at once begin an elaborate series of clean- 
ing reactions involving the antennal funiculi, the fore legs and sometimes the tip of the gaster. A single injury such as might have been received from the mandibles of the attacker would scarcely be expected to evoke such a general response. Moreover, as I shall presently show, injuries are rarely sustained by the Brachymyrmex during the initial attack. Yet this cleaning reaction after the attack is an exceedingly constant one. I observed it so often that I am led to suspect that some irritating substance is ejected by the Strumigenys at the moment of striking. I much regret that I cannot prove this point which is very interesting if true.

While the Brachymyrmex was busy cleaning itself other Strumigenys workers would arrive and encircle it. Although the advantage of a concerted attack would seem obvious I never saw this happen. Each Strumigenys attacks separately moving in with great deliberation and ascertaining the position of the Brachymyrmex with the antennae before striking. It is interesting to note that this particular reaction prevents the Strumigenys from striking each other. Quite frequently the positions of the attackers would be such that they would have struck one another had they relied solely upon the trigger hairs to release the mandibular mechanism. By bringing the antennae into play they were enabled to recognize their nest mates and would alter their position accordingly. In the hundreds of times which I witnessed the Strumigenys attack I never saw one strike a nest mate. During this phase of the attack the Brachymyrmex would, of course, be struck at repeatedly. Not infrequently it would break out of the circle of attackers and run to another part of the nest. This, however, merely delayed the final result for sooner or later it was again surrounded. After the Brachymyrmex had been struck at perhaps twelve or fifteen times it usually became much dejected. It ceased the cleaning movements which it had continued up to this time and made no further attempts to avoid attack. I wish to stress the fact that this dejection, if I may use that term, was not due to injuries. Except in rare cases the Brachymyrmex would reach this stage of the attack without any visible sign that it had sustained damage from the mandibles of its attackers. The change in its reactions was, nevertheless, most pronounced and this again leads me to the conclusion that its 
lethargic condition may have resulted from the cumulative effects of some substance ejected upon it by the Strumigenys.

With the decreasing activity of the Brachymyrmex the Strumigenys became, if possible, more methodical than ever. They would deliberately manoeuver the mandibles so that they would close on a leg or antenna of the victim and the better success of this attack was evidenced by the appearance of injuries in the parts just mentioned. The distress of the Brachymyrmex was now very apparent. It would undergo spasmodic shudderings or lift its body as high as possible with the legs stiff and straight beneath. As a rule it lost the power of muscular coordination a short time afterward and the attack would end with the Brachymyrmex lying on the floor of the nest with its legs drawn tightly beneath it.

In most cases the Strumigenys would later carry out the corpses of their victims and deposit them on the "kitchen midden", in this case one of the food chambers of the nest. I was thus enabled to relax the remains of the Brachymyrmex workers and study the extent and character of the injuries. As might have been expected these were remarkably uniform. The antennal funiculi suffered the most. One or both usually showed injuries involving the loss of several joints. Not infrequently the entire funiculus, except the basal joint, was missing. The fore and middle tarsi, while less frequently damaged than the funiculi, were often injured. The hind tarsi were usually intact. In one specimen the tip of the gaster was torn but this injury was so slight that I would probably not have noticed it had it not been for the actions of the ant while it was still alive. This was the sole injury involving the body of the victim. Although I made a most careful search for evidences of piercing on various parts of the body I never found the slightest indication that the teeth of the attackers had penetrated the integument of the Brachymyrmex. As it would be hard to find an ant in which the integument is softer or thinner than that of Brachymyrmex the lack of body wounds can scarcely be attributed to the inability of the Strumigenys to pierce the chitin. On the contrary it seems obvious that they make little effort to do so preferring rather to cripple the victim by removing the joints of the appendages. While this view 
checks with observed facts it is far from satisfactory as an explanation covering the death of the Brachymyrmex. We may admit that most ants are severely affected by injuries involving the antennae but it rarely happens that such injuries are immediately followed by death. The loss of a tarsal joint or two is usually a matter of slight consequence. Yet in thirteen cases injuries of the nature just described were accompanied by the rapid demise of the victim. Again I find myself led to the view that some substance is ejected by the Strumigenys as they strike at the victim. It would seem necessary to believe that this substance is not only
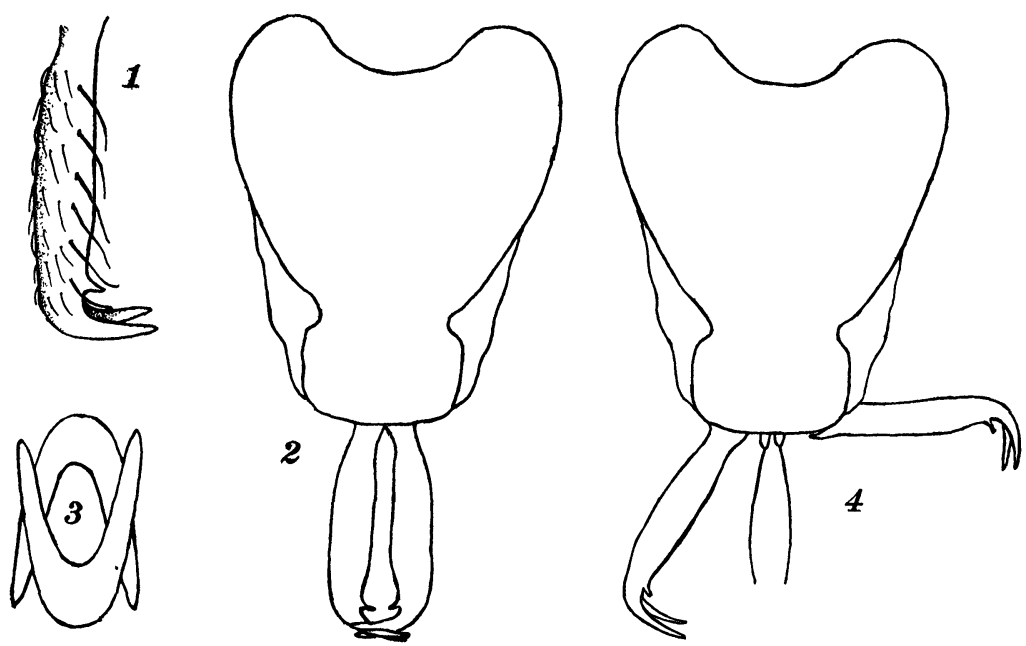

Fig. 1. Cephalic structures of Strumigenys louisianae subsp. laticephala Smith. For explanation of figures see text.

irritating but toxic. Again I must stress the fact that I cannot prove this assumption. It is, however, the only explanation which appears to cover the facts.

I wish to add a few more observations concerning the manner in which the Strumigenys workers use their mandibles. The first of these involves a detailed discussion of the role of the mandible during attack, a matter which is more complex than might be supposed. The extreme rapidity with which the mandibles are closed in striking makes this process very difficult to follow. Repeated observations have, 
however, convinced me that the mandibles of Strumigenys, unlike those of Odontomachus, do not act as shearing organs. I have already pointed out that each time a Strumigenys worker strikes at a victim the closure of the mandibles is immediately followed by a backward jerk of the insect. At first this used to annoy me considerably since it seemed to defeat the whole plan of attack by moving the Strumigenys out of range. I later learned to appreciate the vital part that this sudden backward motion plays in the amputation of appendages on which the mandibles close. It may be readily observed that when the Strumigenys workers close in for the final attack the damages to the antennal funiculi and tarsi of the victim involve mangled joints. The portion of the appendage beyond the injured joint will often bend in a fashion which plainly indicates that the joint has been badly crushed. As a rule the part of the appendage beyond the damaged joint is quickly removed as the result of further attacks. As its final removal is accomplished with the speed of a conjuring trick it was some time before I realized exactly how this is done. It is obvious that the initial damage to the appendage is caused by the flattened inner faces of the mandibles of Strumigenys which crush the joint on which they close but lack the power to completely sever it. I have already pointed out that in repose the mandibles of Strumigenys do not quite meet and this may account for their deficiency as pincers. It might be supposed that the backward jerk which follows this initial damage would sever the appendage but this is not usually the case. I believe that this can be explained if we consider that the crushed joint is free to move along the approximated inner faces of the mandibles which are smooth and without teeth except for the three at the apex. As I have already stated the final removal of the distal portion of a damaged appendage is a very speedy process and I am by no means certain that the method which I am about to describe is invariably employed. There has been ample opportunity, however, to observe that it is frequently used. It involves a relation between the appendage and the mandibles such that the four apical teeth close around the appendage. Because of the shape of the space included between these apical teeth (vide supra) they can lock against the appendage. This is particularly true if the 
latter happens to be an antennal funiculus which increases in diameter toward the tip. The backward jerk of the Strumigenys is then exerted in the direction of the long axis of the already injured appendage which may break in consequence at the damaged joint. It may be added that unless the appendage has been previously crushed it cannot be pulled off when caught by the apical teeth. Under such circumstances there ensues a sort of a tug-of-war with the Strumigenys holding grimly to the appendage and the victim struggling frantically to get free.

Aside from their vital role in attack the mandibles of Strumigenys are little used. They occasionally employ them in carrying nest mates about but this was seldom observed. I never saw any indications that the mandibles play a part in the trophic reactions of these insects. Feeding is entirely cared for by the palps and other mouthparts. When Strumigenys is feeding the mandibles are kept closed and thrust upward over the food until the stubby palps come in contact with its surface. The palps apparently act both as rasps and spoons for both liquids and semisolids are ingested by their help. The feeding reactions of Strumigenys are exceedingly difficult to follow because all the more delicate mouth parts are reduced in size and closely packed into the small buccal cavity. It is interesting to note that the mandibles are kept closed during regurgitation. This results in a rather awkward situation for both regurgitant and recipient. The closed mandibles prevent the usual approximation of the two heads and it is only after considerable preliminary fencing that the correct posture is assumed. Each ant turns its head sidewise so that ventral surfaces are parallel although not opposite. The closed mandibles are then crossed and slid over each other until the palps are close enough for the transfer. It seems a remarkably clumsy way of securing a result which could be easily reached by simply opening the mandibles.

There remains the matter of retrosalience. I saw this phenomenon only twice during the many hours that the captive colony was under observation. In one case it resulted when the mandibles of an attacking Strumigenys worker closed on the convex surface of a glass tube which led to one of the feeding chambers. The resulting leap threw the insect 
against the top of the nest whence it was deflected to the floor at a point not much more than three-quarters of an inch from its original position. Had the leap been unimpeded it would probably have been more extensive. The second case occurred under similar circumstances and with much the same result. As far as I am aware this is the third time in which retrosalience has been reported for a member of the genus Strumigenys. Hetschko (teste Mayr) observed it in the South American S. saliens about 1887 (5) and ten years later Biro (teste Emery) saw the same phenomenon in the case of S. chyzeri which he studied in New Guinea (6). Each of the above accounts is rather meager but it seems likely that both species frequently resorted to retrosalience. It is not impossible that it had come to play a protective role in their habits as is the case with Anochetus and Odontontomachus. I cannot believe that retrosalience plays any such part in the case of $S$. louisianae. The phenomenon is so rare and the conditions which would produce it so unusual that it must play little or no part in the ecology of this form.

\section{LITERATURE CITED}

1. Smith, M. R. Ann. Ent. Soc. America. Vol. XXIV, No. 4, p. 690, (1931).

2. Kennedy, C. H. \& Schramm, M. M. Ibid. Vol. XXVI, No. 1, p. 104, (1933).

3. Wheeler, W. M. \& Bailey, I. W. Trans. American Philos. Soc. N.S., Vol. XXII, No. 4, p. 247-248, (1920).

4. Creighton, W. S. Jour. New York Ent. Soc. Vol. XXXVIII, p. 177, (1930).

5. Mayr, G. Zool-bot. Ges. Wien Vol. XXXVII, p. 575, (1887).

6. Emery, C. Term. Füzetek, Vol. XX, p. 576, (1897). 

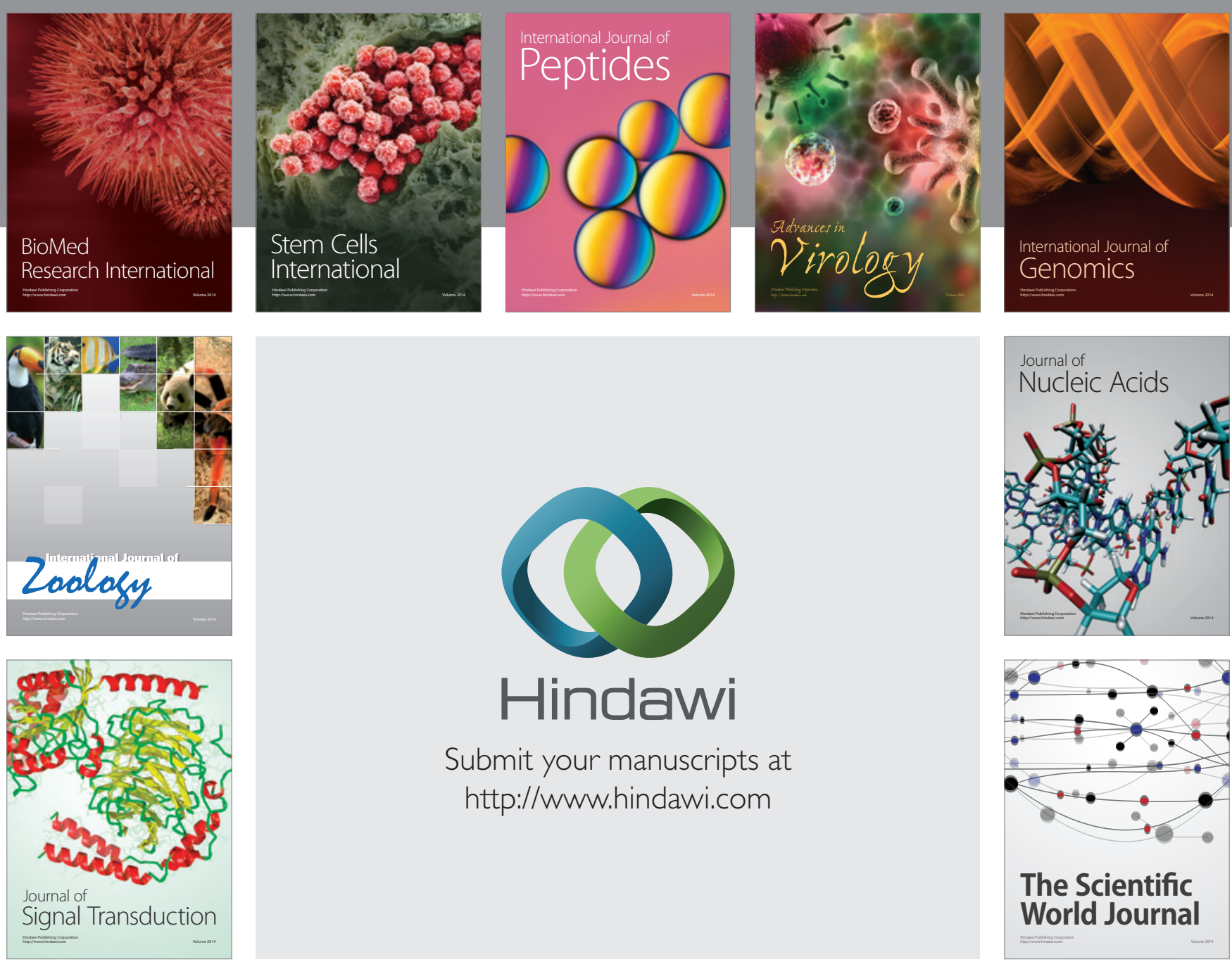

Submit your manuscripts at

http://www.hindawi.com
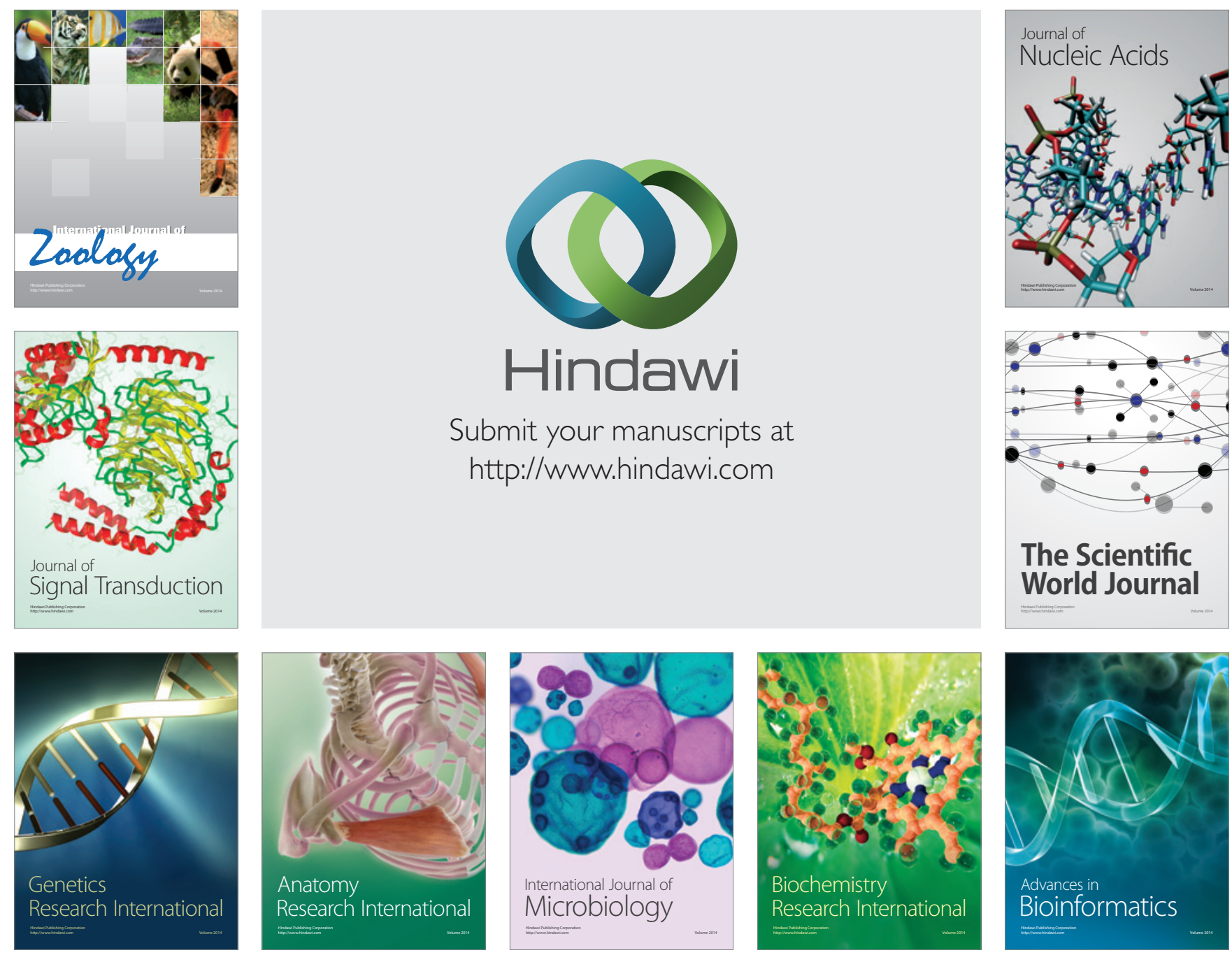

The Scientific World Journal
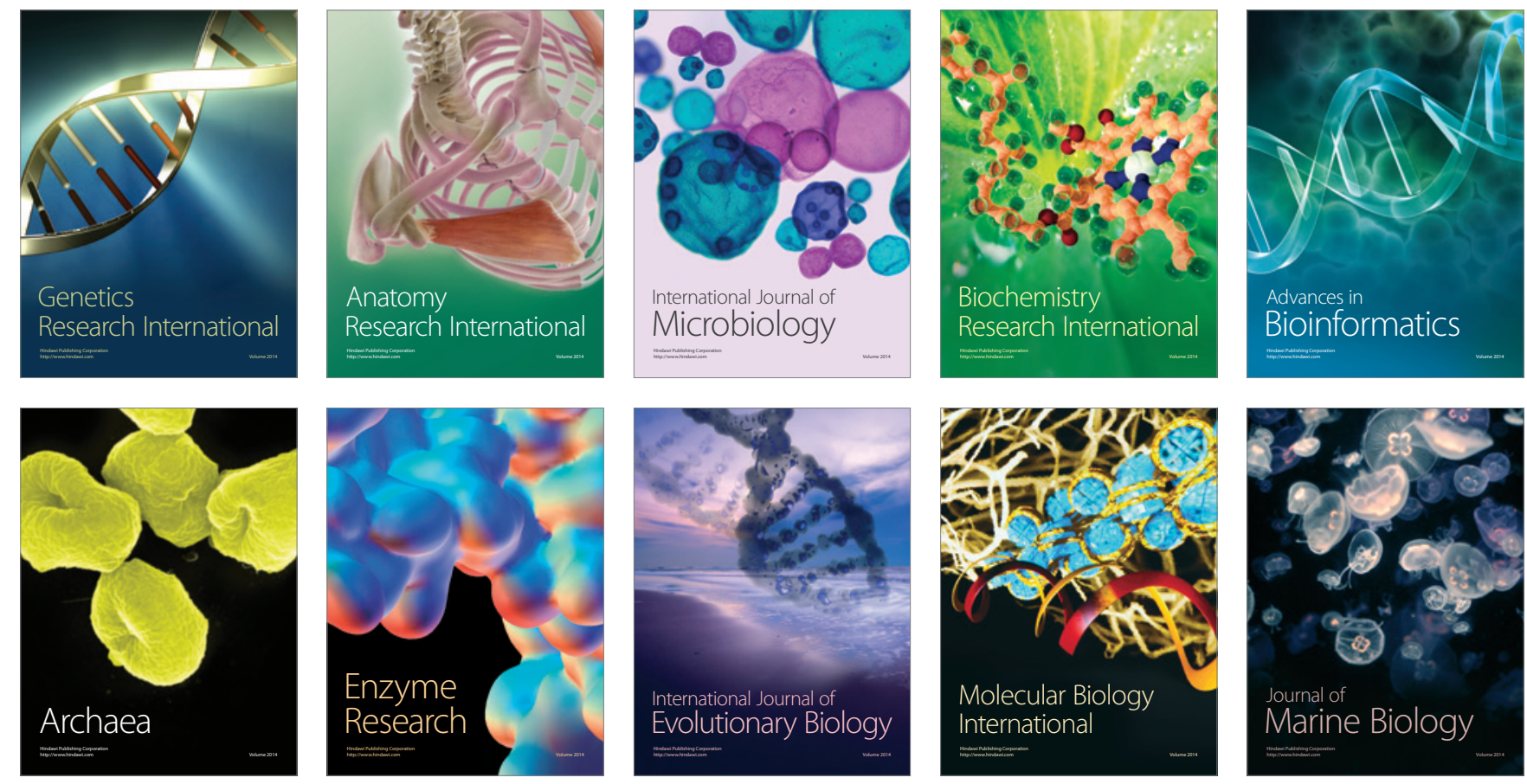